\title{
HUBUNGAN ASUPAN ENERGI JAJANAN DENGAN PRESTASI BELAJAR REMAJA DI SMP PL DOMENICO SAVIO SEMARANG
}

\author{
Kartika Febriani, Ani Margawati") \\ Program Studi Ilmu Gizi Fakultas Kedokteran Universitas Diponegoro \\ Jl.Dr.Sutomo No.18, Semarang, Telp (024) 8453708, Email : gizifk@undip.ac.id
}

\begin{abstract}
Background: Adolescence is a transition period from child to adulthood. Adolescents experiencing physical and psychological development. Optimal energy intake necessary to support the physical and psychological development of adolescents. Adolescents get a high snack energy intake. Snack energy intake allegedly associated with academic achievement. One of the factors associated with good academic performance is optimal energy intake. This study aims to determine the relationship of snacks energy intake with academic achievement in adolescents.

Methods: This study was conducted in SMP PL Domenico Savio Semarang. It was Cross-sectional study design with a sample of 63 subjects. Selection of samples by Consecutive random sampling in grade 7 and 8 regular class. Snacks energy intake were taken using a Food Recall for 3 days. Academic achievement were taken from the average scores of second semester. The association of energy intake of snacks with academic achievement were analized using Chi-square. The association of energy intake of snacks, another energy intake and academic achievement were analized using logistic regression.

Results: This study found that snacks energy intake of 30 subject (47.6\%) were sufficient and 33 subject (52.4\%) were insufficient. Sufficient snacks energy intake and good academic achievement were 20 subjects (55.6\%), insufficient snacks energy intake and good achievement were 16 subjects (44.4\%), snacks sufficient energy intake and bad academic achievement were 10 subjects (37\%), snacks energy intake and bad achievement were 17 subjects (63\%). There was no significant association between snacks energy intake and academic achievement ( $p=$ $0.145)$. There was significant association between another energy intake and academic achievement $(p=0,026)$. Snacks energy intake was not a variable that associates strongly with academic achievement $(p<0,05)$.

Conclusion: Snacks energy intake was not a factor that strongly associated with academic achievement, but another energy intake related to academic achievement.
\end{abstract}

Keywords: snacks energy intake; academic achievement; adolescents

\begin{abstract}
ABSTRAK
Latar belakang: Masa remaja merupakan masa transisi dari anak menuju dewasa. Remaja mengalami perkembangan secara fisik dan psikologi. Perlu asupan energi yang optimal untuk menunjang perkembangan fisik dan psikologi remaja. Remaja mendapat asupan energi jajanan cukup tinggi. Asupan energi jajanan diduga berkaitan dengan prestasi belajar. Salah satu faktor yang berhubungan dengan prestasi belajar yang baik adalah asupan energi yang optimal. Penelitian ini bertujuan untuk mengetahui hubungan asupan energi jajanan dengan prestasi belajar pada remaja di SMP PL Domenico Savio.

Metode: Penelitian ini dilakukan di SMP PL Domenico Savio Semarang. Desain penelitian cross sectional dengan jumlah sampel 63 subjek. Pengambilan sampel penelitian menggunakan consecutive random sampling pada siswa kelas 7 dan 8 reguler. Data asupan energi jajanan dan selain jajanan diambil menggunakan Food Recall 3x24 jam. Data prestasi belajar diambil dari rata- rata nilai rapor semester genap. Hubungan asupan energi jajanan dengan prestasi belajar dianalisis menggunakan uji Chi-square. Hubungan asupan energi jajanan, asupan energi selain jajanan, dan prestasi belajar dianalisis menggunakan uji regresi logistik.

Hasil: Pada penelitian ini ditemukan 30 subjek (47,6\%) asupan energi jajanan cukup dan 33 subjek (52,4\%) asupan energi jajanan kurang. Subjek dengan asupan energi jajanan cukup dan prestasi belajar baik adalah 20 orang (55,6\%), asupan energi jajanan kurang dan prestasi belajar baik adalah 16 orang (44,4\%), asupan energi jajanan cukup dan prestasi belajar kurang adalah 10 orang (37\%), subjek yang asupan energi jajanan kurang dan prestasi belajar kurang adalah 17 orang (63\%). Tidak terdapat hubungan yang bermakna antara asupan energi jajanan dengan prestasi belajar $(p=0,145)$. Terdapat hubungan yang bermakna antara asupan energi selain jajanan dan prestasi belajar $(p=0,026)$. Asupan energi dari jajanan bukan merupakan variabel yang berhubungan kuat dengan prestasi belajar $(p<0,05)$.
\end{abstract}

Simpulan: Asupan energi jajanan bukan merupakan faktor yang berhubungan kuat dengan prestasi belajar, tetapi asupan energi selain jajanan berhubungan dengan prestasi belajar.

Kata kunci: Asupan energi jajanan; prestasi belajar; remaja 


\section{PENDAHULUAN}

Masa remaja merupakan periode transisi antara anak menuju dewasa. Masa remaja adalah masa penting dalam daur kehidupan manusia karena secara umum terjadi perkembangan fisik dan psikologis dari anak menjadi dewasa. Keseimbangan asupan yang dibutuhkan selama masa remaja dapat mengoptimalkan perkembangan dan pertumbuhan pada remaja. ${ }^{1,2}$ Masa remaja merupakan periode persiapan untuk mengurangi risiko masalah gangguan pertumbuhan fisik dan psikologis di masa mendatang. Namun, masa remaja juga merupakan periode penuh risiko yang diakibatkan oleh perilaku yang tidak tepat. ${ }^{3}$

Remaja mendapatkan asupan energi jajanan cukup tinggi. ${ }^{2}$ Penelitian di Bogor pada tahun 2009 menyatakan $46 \%$ anak mengonsumsi 6-7 jenis jajanan per minggu. ${ }^{4}$ Hasil survey pada tahun 2005-2006 di Amerika, 83\% remaja mengonsumsi jajanan setidaknya 1 kali dalam sehari. $^{5}$ Suatu penelitian cross sectional di Australia pada tahun 2007 menunjukan presentasi waktu konsumsi jajanan remaja yaitu $34 \%$ setelah sekolah, $16 \%$ selama menonton televisi, $10 \%$ saat diluar rumah, $6 \%$ selama mengerjakan tugas rumah, 4\% saat perjalanan dari sekolah, 3\% sepanjang hari, dan $2 \%$ saat tengah malam. ${ }^{6}$

Penelitian di Indonesia pada tahun 2009 menyatakan asupan energi jajanan memberikan kontribusi dalam pemenuhan kecukupan energi sebesar 10-20\%. ${ }^{4}$ Berdasarkan kutipan hasil survey di Amerika, 20\% total asupan makanan berasal dari jajanan. ${ }^{7}$ Hasil penelitian di Indonesia pada tahun 2005 yang dilakukan di dua sekolah dasar menyatakan bahwa asupan energi jajanan memiliki kontribusi energi $15,7 \%$ dan $10,81 \% .^{8}$ Namun, penelitian mengenai kontribusi nutrisi dari jajanan di Jawa Barat pada tahun 2012 menyatakan bahwa jajanan memiliki kontribusi vitamin dan mineral yang rendah. ${ }^{9}$ Hasil penelitian di Malaysia tahun 2012 menunjukan $16 \%$ siswa dengan pola makan 3 kali makan utama dan 3 selingan memiliki asupan energi total tertinggi dibanding dengan kategori pola makan lainnya ( 3 kali makan utama dan 2 kali selingan atau 3 kali makan utama dan 1 kali selingan). ${ }^{10}$

Asupan energi jajanan dapat mempengaruhi status gizi karena asupan jajanan yang berlebih dalam satu hari berhubungan dengan peningkatan asupan total kalori. ${ }^{5}$ Hasil penelitian di Semarang pada tahun 2012 menyatakan bahwa subjek yang asupan jajanannya mengandung energi $\geq 10 \%$ dan $>5$ kali dalam seminggu memiliki risiko 7 kali terhadap status gizi lebih. ${ }^{11}$ Remaja yang suka mengonsumsi jajanan cenderung meninggalkan makan utamanya dibanding remaja yang tidak suka mengonsumsi jajanan. ${ }^{6}$ Apabila asupan energi jajanan dan makanan tidak memenuhi kebutuhan energi total akan mengalami kekurangan energi dan berdampak pada status gizi kurang/buruk, begitu juga sebaliknya. ${ }^{10}$ Selain itu, pemilihan jenis jajanan yang dikonsumsi juga dapat mempengaruhi status gizi. Jajanan yang mengandung tinggi gula dan lemak sangat erat hubungannya dengan kejadian overweight. ${ }^{12}$

Penelitian korelasi antara perilaku makan dan status gizi dengan prestasi belajar pada siswa Sekolah Menengah Pertama (SMP) di Malang tahun 2011 menyatakan terdapat hubungan yang signifikan antara perilaku makan dan status gizi dengan prestasi belajar. ${ }^{13}$ Hasil penelitian mengenai hubungan kecerdasan dengan pola makan, aktivitas fisik, dan berat badan remaja pada tahun 2008 menunjukan bahwa kecerdasan memiliki hubungan yang positif dengan pola makan. ${ }^{14}$ Penelitian serupa mengenai hubungan kemampuan kognitif dengan kebiasaan makan, aktivitas fisik, dan berat badan di Belanda pada tahun 2010 menyatakan bahwa remaja dengan kebiasaan makan sehat dan aktivitas fisik lebih sering memiliki score kemampuan kognitif lebih tinggi. ${ }^{15}$ Suatu penelitian cross sectional di Indonesia pada tahun 2011 menyatakan bahwa konsumsi jajanan saat istirahat memiliki hubungan yang signifikan dengan konsentrasi belajar pada kelompok remaja. ${ }^{16}$

Penelitian dilakukan di Sekolah Menengah Pertama (SMP) PL Domenico Savio. SMP PL Domenico Savio merupakan salah satu sekolah swasta di Semarang. Tingkat ekonomi keluarga siswa yang menengah keatas memungkinkan siswa untuk mengakses jajanan lebih banyak. Berdasarkan hasil nilai ujian nasional tahun 2013, SMP PL Domenico savio mendapat peringkat kedua di Semarang. Oleh karena itu, peneliti ingin mengetahui hubungan asupan jajanan dengan prestasi belajar remaja di SMP PL Domenico Savio.

\section{METODE}

Studi ini lingkup gizi masyarakat dan merupakan studi observasional dengan desain cross sectional. Lokasi penelitian dilaksanakan di SMP PL Domenico Savio Semarang pada bulan Juni 2013.

Populasi pada penelitian ini adalah seluruh siswa-siswi kelas 7 dan 8 reguler sejumlah 700 orang. Jumlah subjek minimal yang dibutuhkan 
sebanyak 61 orang. Total subjek yang didapatkan dalam penelitian ini sebanyak 63 orang dengan metode pengambilan consecutive random sampling. Kriteria inklusi yaitu remaja perempuan dan laki-laki berusia $13 \quad-14$ tahun, bersedia mengikuti penelitian, rercatat sebagai siswa di SMP Domenico Savio, dan merupakan siswa kelas 7 atau 8.

Data yang dikumpulkan meliputi indentitas subjek, uang saku, asupan energi jajanan sebagai variabel bebas, asupan energi selain jajanan sebagai variabel perancu, dan prestasi belajar sebagai variabel terikat. Data identitas subjek dan uang saku diambil secara wawancara, berdasarkan kuesioner. Asupan energi jajanan dan selain jajanan diperoleh menggunakan Food Recall 3 x 24 jam. Perhitungan asupan energi jajanan dan selain jajanan menggunakan program komputer. Asupan energi jajanan adalah asupan yang berasal dari kudapan (snack) dan minuman, bukan makanan lengkap yang dikonsumsi pada saat makan pagi (jam 06.00-07.00), makan siang (jam 12.00-14.00), dan makan malam (jam 19.0020.00), serta mengandung energi sebesar 10\%-20\% dari kebutuhan total sehari. Asupan jajanan dikategorikan cukup jika mengandung energi sebesar $\geq 10 \%$ dari kebutuhan total sehari, sedangkan asupan jajanan dikategorikan kurang jika mengandung energi sebesar $<10 \%$ dari kebutuhan total sehari. Asupan energi selain jajanan adalah asupan energi total dikurangi asupan energi jajanan. Asupan energi selain jajanan dikategorikan cukup jika $\geq$ kebutuhan energi - asupan energi dari jajanan, sedangkan asupan energi selain jajanan dikategorikan kurang jika < kebutuhan energi - asupan energi dari jajanan. Kebutuhan energi diperoleh dari Widyakarya Nasional Pangan dan Gizi VIII tahun 2004.

Data prestasi belajar diperoleh dari jumlah rata-rata nilai rapor semester genap. Prestasi belajar dikategorikan baik apabila rata-rata nilai rapor subjek > rata-rata nilai rapor siswa kelas 7 dan 8 reguler SMP PL Domenico savio, sedangkan prestasi belajar dikategorikan buruk apabila ratarata nilai rapor subjek < rata-rata nilai rapor siswa kelas 7 dan 8 reguler SMP PL Domenico Savio.

Pengolahan dan analisis data dilakukan dengan program komputer. Analisis univariat digunakan untuk mendeskripsikan karakteristik sampel dan variabel penelitian. Analisis bivariat digunakan untuk mengetahui hubungan asupan jajanan dengan prestasi belajar dan asupan energi selain jajanan dengan prestasi belajar menggunakan uji Chi-square. Analisis multivariat yang dilakukan adalah uji regresi logistik karena variabel terikatnya berupa variabel kategorik.

\section{HASIL PENELITIAN \\ Karakteristik Subjek Penelitian}

Subjek penilitian yang diperoleh sebanyak 63 orang yang jumlah laki-laki dan perempuannya hampir sama. Subjek yang merupakan siswa kelas 7 lebih banyak dari kelas 8. Usia subjek penelitian sesuai dengan kriteria inklusi 13-14 tahun, dengan proporsi lebih banyak usia 14 tahun dibanding usia 13 tahun. Rata-rata uang saku subjek lebih dari 5000 rupiah. Karakteristik subjek dapat dilihat pada Tabel 1.

Tabel 1. Karakteristik Subjek Penelitian

\begin{tabular}{lcc}
\hline \multicolumn{1}{c}{ Karakteristik Subjek } & n & \% \\
\hline Jenis Kelamin & & \\
$\quad$ Laki-laki & 31 & 49,2 \\
$\quad$ Perempuan & 32 & 50,8 \\
Usia & & \\
$\quad$ 13 Tahun & 27 & 42,9 \\
14 Tahun & 36 & 57,1 \\
Uang Saku & & \\
$\quad<5000$ & 5 & 7,9 \\
$5000-10000$ & 36 & 57,1 \\
$>10000$ & 22 & 34,9 \\
\hline Total & 63 & 100 \\
\hline
\end{tabular}


Gambaran Umum Lokasi Jajanan yang Biasa dikunjungi

Salah satu lokasi jajanan yang biasa dikunjungi subjek diluar rumah adalah kantin/pedagang jajanan diluar sekolah . Kantin sekolah menjual berbagai macam jajanan dan minuman antara lain, tempe goreng, pisang goreng, martabak, dan lunpia, chiki, biskuit kemasan, wafer kemasan, premen, es teh, susu kemasan, dan air. Selain itu, terdapat pedagang yang menjajakan makanan diluar sekolah. Penjual diluar sekolah menjual berbagai macam jajanan dan minuman antara lain siomay, bakso, dan beberapa makanan dan minuman yang hampir sama dengan yang dijual kantik sekolah. Subjek dapat membeli jajanan diluar sekolah saat sekolah selesai atau saat ekstrakurikuler. Dengan adanya uang saku dan pedagang jajanan di kantin maupun diluar sekolah, subjek akan lebih sering mengonsumsi jajanan saat di sekolah.

\section{Karakteristik Variabel Penelitian}

Rata-rata asupan energi jajanan sebesar 250 kalori dengan asupan terendah 40 kalori dan asupan tertinggi 693 kalori. Persentase kontribusi jajanan terhadap total kebutuhan kalori sehari subjek sebesar $1,7 \%$ - 29,5\%. Frekuensi subjek mengonsumsi jajanan minimal 1 kali sehari. Jenis makanan yang sering dikonsumsi adalah tempe goreng, pisang goreng, dan makanan kemasan pabrik antara lain permen, chiki, dan biskuit. Jenis minuman yang sering dikonsumsi adalah es teh manis dan susu kemasan. Subjek paling sering mengonsumsi jajanan pada saat di sekolah. Hal tersebut memungkinkan terjadi asupan energi jajanan yang tinggi saat di sekolah.

Prestasi belajar diperoleh dari rata-rata nilai rapor semester genap. Rata-rata nilai rapor siswa kelas 7 dan 8 reguler di SMP PL Domenico Savio adalah 80. Rata- rata nilai rapor minimum subjek penelitian adalah 72,9 dan maksimum adalah 88,9. Selain mendapatkan pelajaran di sekolah beberapa siswa mengikuti les atau bimbingan belajar diluar jam sekolah.

Rata-rata asupan energi selain jajanan sebesar 2220 kalori dengan asupan terendah 1535 kalori dan asupan tertinggi 2702 kalori. Pola makan 3 kali sehari telah dilakukan hampir seluruh subjek. Namun, subjek memiliki waktu makan pagi, siang, dan malam yang berbeda-beda.

Asupan energi jajanan, asupan energi selain jajanan, dan prestasi belajar dapat dilihat pada Tabel 2.

Tabel 2. Karakteristik Variabel Penelitian

\begin{tabular}{lll}
\hline \multicolumn{1}{c}{ Karakteristik } & n & \% \\
\hline Asupan Energi Jajanan & & \\
Cukup & 30 & 47,6 \\
Kurang & 33 & 52,4 \\
Prestasi Belajar & & \\
Baik & 36 & 57,1 \\
Buruk & 27 & 42,9 \\
Asupan Energi Selain Jajanan & & \\
Cukup & 38 & 60,3 \\
Kurang & 25 & 39,7 \\
\hline Total & 63 & 100 \\
\hline
\end{tabular}

\section{Analisis Bivariat}

Berdasarkan hasil analisis uji Chi-square pada variabel asupan energi jajanan dengan prestasi belajar didapatkan $p$-value 0,145 , sehingga dapat disimpulkan bahwa tidak terdapat hubungan yang bermakna antara asupan jajanan dengan prestasi belajar.

Faktor lain yang dapat mempengaruhi prestasi belajar adalah asupan energi selain jajanan. Berdasarkan hasil analisis uji Chi-square pada variabel asupan energi selain jajanan dengan prestasi belajar didapatkan $p$-value 0,026 , sehingga dapat disimpulkan bahwa terdapat hubungan yang bermakna antara asupan energi selain jajanan dengan prestasi belajar.

Hasil analisis bivariat antara asupan energi jajanan dan asupan energi selain jajanan dengan prestasi belajar dapat dilihat pada Tabel 3 . 
Tablel 3. Hasil Analisis Bivariat

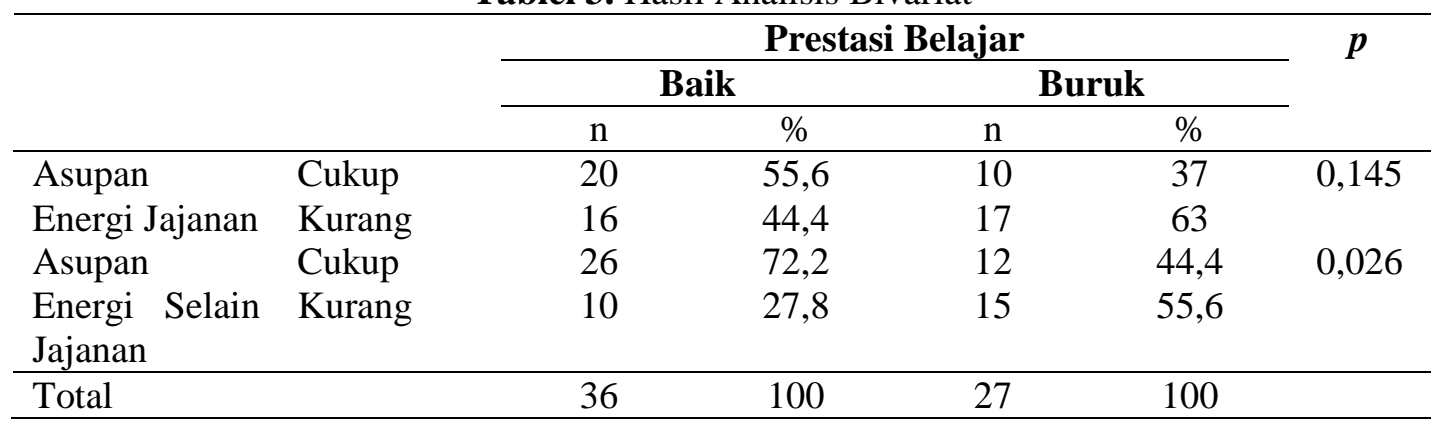

\section{Analisis Multivariat}

Hasil analisis uji hubungan antara asupan energi jajanan dengan prestasi belajar setelah dikontrol asupan energi selain jajanan menunjukkan bahwa tidak terdapat hubungan yang bermakna $(p<0,05)$. Hasil analisis multivariat regresi logistik dapat dilihat pada Tabel 4.

Tablel 4. Hasil Analisis Multivariat

\begin{tabular}{lcccccc}
\hline \multicolumn{1}{c}{ Variabel } & B & SE & p-value & $\operatorname{Exp(B)}$ & \multicolumn{2}{c}{$\begin{array}{c}\mathbf{9 5 \%} \text { C.I for } \\
\operatorname{Exp}(\mathbf{B})\end{array}$} \\
\cline { 5 - 7 } & & & & & Lower & Upper \\
\hline Asupan Energi Jajanan & $-0,745$ & 0,542 & 0,170 & 0,473 & 0,164 & 1,374 \\
Asupan Energi Selain & $-1,173$ & 0,546 & 0,032 & 0,310 & 0,106 & 0,093 \\
Jajanan & & & & & & \\
\hline
\end{tabular}

\section{PEMBAHASAN}

Asupan energi berasal dari asupan makanan sehari-hari salah satunya asupan energi jajanan. Asupan energi jajanan dalam penelitian ini adalah asupan yang berasal dari kudapan (snack), bukan makanan lengkap yang dikondumsi pada saat makan pagi, siang, dan malam, serta mengandung energi sebesar 10-20\%. Berdasarkan hasil analisis hasil Food Recall, subjek mendapat frekuensi subjek mengonsumsi jajanan minimal 1 kali sehari. Hasil survey pada tahun 2005-2006 di Amerika, $83 \%$ remaja mengonsumsi jajanan setidaknya 1 kali dalam sehari. ${ }^{5}$ Selain itu, penelitian Teo Yee Boon, et al pada tahun 2012 yang menunjukkan presentase subjek yang mengonsumsi jajanan $\geq 1$ kali sehari sebesar $97,4 \% .{ }^{10}$ Hal ini mendukung pernyataan bahwa asupan energi jajanan pada remaja cukup tinggi. ${ }^{2}$

Asupan energi dari jajanan subjek diperoleh saat di rumah atau diluar rumah. Asupan energi jajanan saat diluar rumah antara lain saat di sekolah, di bioskop, di pusat perbelanjaan, atau di rumah teman. Berdasarkan hasil wawancara, subjek sering mendapat asupan energi dari jajanan saat di sekolah. Asupan jajanan disekolah dapat terjadi karena adanya uang saku. Rata-rata uang saku subjek > 5000 rupiah yang artinya subjek dapat membeli setidaknya 1 jenis jajanan.
Rata-rata asupan energi dari jajanan pada penelitian ini sebesar 250 kalori dengan asupan minimum 40 kalori dan asupan maksimum 639 kalori. Hal ini berarti bahwa masih terdapat subjek yang asupan energi dari jajanannya kurang. Asupan energi dari jajanan sebaiknya tidak dihilangkan dari asupan harian karena memberikan sumbangan energi yang cukup berarti. ${ }^{17}$ Jajanan memberikan sumbangan energi bagi subjek yang meninggalkan waktu makan pagi. Namun, pemilihan jajanan juga harus diperhatikan.

Prestasi belajar merupakan salah satu ukuran dari tingkat kecerdasan siswa. Prestasi belajar siswa-siswi SMP PL Domenico tergolong tinggi dengan rata-rata nilai rapor kelas 7 dan kelas 8 reguler sebesar 80. Faktor kecukupan energi dan gizi dapat mempengaruhi prestasi belajar karena asupan energi dan zat gizi yang tidak optimal akan mengganggu perkembangan otak. ${ }^{1}$ Berdasarkan hasil analisis bivariat antara asupan energi dari jajanan dengan prestasi belajar menyatakan bahwa tidak terdapat hubungan yang bermakna antara asupan energi jajanan dengan prestasi belajar. Pada penelitian ini ditemukan subjek dengan asupan energi jajanan kurang dan prestasi baik sebanyak 16 orang $(44,4 \%)$. Hasil penelitian Ahmawati Prapti M.R. pada tahun 2008 menyatakan bahwa selain faktor status gizi, faktor lingkungan belajar 
dan fasilitas belajar juga dapat mempengaruhi prestasi belajar. ${ }^{18}$ Berdasarkan hasil observasi, subjek belajar dengan ruang belajar yang nyaman. Setiap ruangan kelas diisi 30 siswa dengan suhu yang nyaman karena adanya pendingin ruangan. Kebersihan ruangan juga terjaga dengan adanya jadwal piket harian, sehingga isi ruangan bersih dan tertata rapi selama kegiatan belajar mengajar berlangsung. Berdasarkan hasil wawancara, subjek memiliki jam belajar selain di sekolah dengan mengikuti les/bimbingan belajar. Dengan demikian subjek dapat memperoleh prestasi belajar yang baik.

Hasil penelitian oleh Masdewi, et al pada tahun 2011 menyatakan perilaku makan mempengaruhi prestasi belajar. Hal ini menunjukan bahwa perilaku makan yang baik maka siswa akan lebih mudah berkonsentrasi, sehingga siswa akan mendapat prestasi yang memuaskan dan maksimal. ${ }^{13}$ Penelitian di Belanda pada tahun 2010 menyatakan bahwa remaja degan kebiasaan makan sehat dan aktivitas fisik lebih sering memiliki score kemampuan kognitif lebih tinggi. ${ }^{15}$ Asupan energi jajanan yang kurang harus diimbangi dengan asupan selain jajanan yang mengandung energi cukup, sehingga kebutuhan energi subjek dapat terpenuhi. Hasil penelitian ini menyatakan adanya hubungan antara asupan energi selain jajanan dengan prestasi belajar. Subjek yang asupan energi dari jajanan kurang tetapi asupan energi selain jajanan mencukupi kebutuhan energi dapat memberikan dampak positif bagi prestasi belajar subjek.

Pada penelitian ini ditemukan kebiasaan diet yang kurang baik yaitu beberapa dari subjek meninggalkan waktu makan pagi, siang, dan malam setelah makan jajanan. Hal ini tidak sesuai dengan penelitian oleh Wanda Koszewski dan Natalie Sehi pada tahun 2012 yang menyatakan bahwa konsumsi jajanan hanya sebagai pelengkap makan utama, bukan pengganti makanan utama. ${ }^{19}$ Apabila asupan energi dari jajanan kurang dan subjek meniggalkan makan utama, kebutuhan energi subjek tidak akan tercukupi. Subjek yang kebutuhan energi yang cukup memiliki memiliki performa belajar yang baik, sehingga subjek dapat menghasilkan prestasi belajar yang baik.

\section{KETERBATASAN PENELITIAN}

Faktor lain yang mempengaruhi prestasi belajar seperti status gizi dan status kesehatan belum diteliti. Selain itu, asupan energi jajanan pada hari sekolah dan hari libur belum diteliti apakah ada perbedaan atau tidak.

\section{KESIMPULAN}

Asupan energi jajanan bukan merupakan faktor yang berhubungan kuat dengan prestasi belajar $(\mathrm{p}=0,170)$, tetapi asupan energi selain jajanan berhubungan dengan prestasi belajar $\mathrm{p}=0,032$ ).

\section{SARAN}

1. Menginformasikan dan mengarahkan mengenai jajanan yang sehat serta makanan yang seimbang dalam mata pelajaran Penjaskes (Pendidikan Jasmani dan Kesehatan) dan unit kesehat sekolah.

2. Perlu diadakan intervensi pada pihak yang memiliki keterkaitan erat dengan subjek (orang tua dan guru), seperti menginformasikan bahwa jajanan memberikan kontribusi energi yang cukup berarti, tetapi tetap memperharikan kandungan zat gizi dalam jajanan tersebut.

\section{UCAPAN TERIMAKASIH}

Puji syukur kepada Tuhan Yang Maha Esa. Terimakasih penulis sampaikan kepada pihak SMP PL Domenico Savio Semarang atas kerjasama dan partisipasi dalam penelitian ini. Terimakasih penulis sampaikan pula kepada Dra. Ani Margawati, M.Kes., Ph.D. selaku dosen pembimbing dan para reviewer, dr. Aryu Candra K., M.Kes. Epid dan Etika Ratna Noer, S.Gz., M.Si, atas kritik dan saran yang membangun serta semua pihak yang telah membantu kelancaran penyusunan artikel ini.

\section{DAFTAR PUSTAKA}

1. Soetjiningsih. Tumbuh Kembang Remaja dan Permasalahannya. Jakarta: CV Sagung Seto. 2010

2. L. Kathleen Mahan dan Sylvia Escott-Stump. Krause's Food \& Nutrition Therapy. Canada: Saunders. 2008

3. Department of Child and Adolescent Health and Development (CAH). Adolescent Health and Development. World Health Organization, 2009.

4. Yunita Syafitri, Hidayat Syarief, dan Yayuk Farida Baliwati. Kebiasaan Jajan Siswa Sekolah Dasar (Studi Kasus di SDN Lawanggintung 01 Bogor). Jurnal Gizi dan Pangan 2009

5. Rhonda S. Sebastian, Joseph D. Goldman, dan Cecilia Wilkinson Enns. Snacking Pattern U.S. Adolescents. Food Surveys Research Group Dietary Data Brief (No. 2) 2010

6. Gayle Savige, Abbie MacFarlane, Kylie Ball, Anthony Worsley dan David Crawford. 2007. Snacking Behaviour of adolescents and their association with skipping meals. International Journal of Behavioral Nutrition and Physical Activity 2007 
7. The NPD Group. Snacking in America. Chicago: The NPD Group's Food and Beverage in Rosemont, 2012

8. Sulistyanto, Joko. Kontribusi Makanan Jajanan terhadap Tingkat Kecukupan Energi dan Protein serta Satus Gizi dalam Kaitannya dengan Prestasi Belajar Anak Sekolah Dasar (Studi di SD H Isriati dan SDN Bendungan Semarang). Semarang: Program Pendidikan Sarjana Fakultas Kedokteran Universitas Diponegoro; 2005

9. Makiko Sekiyama, Katrin Roosita, Ryutaro Ohtsuka. Snack foods consumption contributes to poor nutrition of rural children in West Java, Indonesia. Asia Pac J Clin Nutr 2012

10. Teo Yee Boon, Razalee Sedek dan Zalifah Mohd Kasim. Association between snacking patterns, energy and nutrient intakes, and body mass index among school adolescents in Kuala Lumpur. American Journal of Food and Nutrition 2012

11. Yanti Mariza, Yuni. Hubungan antara Kebiasaan Sarapan dan Kebiasaan Jajan dengan Status Gizi pada Anak Sekolah Dasar di Kecamatan Pedurungan Kota Semarang. Journal of Nutrition College 2012

12. M. Steiner-Asiedu, J.E. Jantuah dan A.K. Anderson. The Snacking Habits in Junior High School Students: The Nutritional Implication-a Short Report. Asian Journal of Medical Sciences 2012

13. Masdewi, Mazarina Devi, Teti Setiawati. Korelasi Perilaku Makan dan Status Gizi Terhadap Prestasi Belajar Siswa Program Akselerasi di SMP. Teknologi dan Kejuruan, VOL. 34, NO. 2; September 2011

14. Margit van Kampen. Intelligence and self control in relation to eating pattern, physical activity and bodyweight in adolescents. University of Utrecht, 2008

15. Marianne Junger and Margit van Kampen. Cognitive ability and self-control in relation todietary habits, physical activity and bodyweight in adolescents. International Journal of Behavioral Nutrition and Physical Activity 2010

16. Mohammad Muchtar, Madarina Julia, Indria Laksmi Gamayanti. Sarapan dan Jajan Berhubungan Dengan Kemampuan Konsentrasi pada Remaja. Jurnal Gizi Klinil Indonesia 2011

17. Umardani, Mawi Rizki. Kebiasaan jajan, aktifitas fisik, status gizi dan kesehatan serta hubungannya dengan prestasi belajar siswa Sekolah Dasar di Kota Bogor. Institut Pertanian Bogor; 2011

18. Rina, Ahmawati Prapti Mahendra. Konsumsi Pangan, Status Gizi, dan Prestasi Belajar SiswaSiswi SMA Assalaam Surakarta. Rogram Studi Gizi Masyarakat dan Sumber Keluarga Fakultas Pertanian Institut Pertanian Bogor; 2008

19. Wanda Koszewski dan Natalie Sehi. Nutrition for School-Aged Child. University of Nebraska Lincoln; 2012 